\title{
The Impacts of Climate Change on Agricultural Trade in the MENA Region
}

\author{
Mahmut Tekce ${ }^{1} \&$ Pinar Deniz ${ }^{1}$ \\ ${ }^{1}$ Department of Economics, Marmara University, Istanbul, Turkey \\ Correspondence: Mahmut Tekce, Department of Economics, Marmara University, Goztepe Campus, 34722, Istanbul, \\ Turkey. Tel: 90-216-336-8487.
}

Received: September 19, 2016

Accepted: October 18, 2016

Online Published: November 24, 2016

doi:10.5430/rwe.v7n2p1

URL: http://dx.doi.org/10.5430/rwe.v7n2p1

\begin{abstract}
Human-induced climate change has been one of the most widely discussed issues of scientific and political spheres in the recent decades, and it has been overwhelmingly agreed that climate change poses a very serious threat for the environment and the economy. It has been observed that increasing temperatures and extremities in weather patterns create a serious challenge for agriculture and food security especially in various disadvantaged regions. Even in the most optimistic scenarios, where global mean temperatures rise by around $2^{\circ} \mathrm{C}$ by 2100 , serious negative effects are expected on agricultural production and crop yields over the next century.

The Middle East and North Africa (MENA) is one of the most vulnerable regions as one of the most food-import dependent region in the world. Water resources are scarce and irrigation is not sufficiently developed in the region, and climate change hurts the already vulnerable agricultural supply, where on the other hand increasing population continuously fosters the demand for agricultural products.

The aim of this paper is to examine the impacts of climate change on agricultural trade in the MENA region. The indicators for climate change includes variables such as precipitation patterns and temperatures, and the effect of the change in the climate change indicators on agricultural exports and imports will be analyzed through a panel data analysis, where the impacts of GDP, per-capita oil use and trade integration will also be added as variables.
\end{abstract}

Keywords: agricultural trade, climate change, oil consumption

\section{Introduction}

Climate change has become a serious worldwide challenge in the last couple of decades such that numerous meetings, negotiations and cooperation attempts are held globally to reverse the problem or mitigate the effects. Recently, the Paris Climate Change agreement, that was signed in December 12, 2015 recognized that "climate change represents an urgent and potentially irreversible threat to human societies and the planet and thus requires the widest possible cooperation by all countries" (IPCC, 2015, 1). With the Agreement, developed and developing countries are required to limit their greenhouse gas (GHG) emissions to relatively safe levels, of $2^{\circ} \mathrm{C}$, with an aspiration of $1.5^{\circ} \mathrm{C}$. Also financial assistance will be provided to poor nations to help them curb carbon emissions and cope with the adverse effects of global warming (Note 1). Global warming is a fact, proven by scientific evidence. It has been observed that global temperature in the first decade of the 21 st century was about $0.8^{\circ} \mathrm{C}$ warmer than at the beginning of the 20 th century (1880-1920 mean); where two thirds of the warming has occurred since 1975 (Hansen et al., 2010, 12). Trend of global warming has accelerated after the late $1970 \mathrm{~s}$, to $0.15^{\circ} \mathrm{C}-0.20^{\circ} \mathrm{C}$ (Hansen et al., 2010, 25).

As its adverse effects intensify, global warming poses a serious threat to all aspects of eco-system and economy. According to IPCC, systems with limited adaptive capacity, such as Arctic sea ice and coral reefs are subject to very high risks with additional warming of $2^{\circ} \mathrm{C}$, and extreme events, such as heat waves, heavy precipitation and coastal flooding, are expected to increase progressively with further warming. These changes would lead to a serious biodiversity loss and irreversible changes, where decreases in regional crop yields and water availability, would create greater risks for disadvantaged people and communities (IPCC, 2014, 72).

Agriculture is considered to be one of the most vulnerable sectors to the adverse effects of climate change. Negative effects of climate change on agriculture, caused by land degradation, water shortages and crop failures, affect the economies of the developing countries more severely as a large share of people in developing countries depend on agricultural incomes for living, and their ability of adaptation to new conditions (due to lack of financial power) are 
worse compared to developed economies. The impacts of climate change on agricultural sector not only results as an increasing trend of migration from (and among the regions of) developing countries (Waldinger, 2015), but also leads to increased mortality among the rural population (Burgess et al., 2014).

As the IPCC (2013) report shows, for each $1^{\circ} \mathrm{C}$ of temperature increase, grain yields decline by about 5 per cent. Maize, wheat and other major crops have experienced significant yield reductions at the global level of 40 megatonnes per year between 1981 and 2002 due to a warmer climate. According to IPCC (2014), although global warming is expected to have some positive effects in high latitude regions due to increased water resources, the global aggregate effect of climate change on crop yields is significantly negative. In low-latitude regions, for example, Tamiotti et al. $(2009,18)$ projects that the decline of crop yields could even reach $50 \%$ by 2020 , and the decline in major cereal crops is projected to be 5 to $10 \%$ even in the temperature increase of around $1{ }^{\circ} \mathrm{C}(\mathrm{Nyong}$, 2009). Cline (2008) argues that climate change in the form of temperature increase tends to reduce agricultural output as the crops speed through their development and bring about less grain in the process. There are other climate conditions that may have impact on agricultural facilities, such as number of frost day frequency, precipitation, vapor pressure, wet day frequency, etc. The extreme weather condition of the frequency of heavy precipitation have increased even in the regions that reflect a decline in the total precipitation, i.e., sub-tropical and mid-latitude regions (Tamiotti et al., 2009, 14).

World trade expanded tremendously in the past 50-60 years and most of it is attributed to technological changes which lowered transportation and communication costs providing a further motivation for trade facilities. Under the assumption that the trading system can be seen as a risk spreading mechanism through the geographic relocation of world food supplies according to changing comparative advantage and spatial diversification of climatic risks, Nyong (2008) explains that "trade liberalization is expected to lead to improvements in access to international markets, which in turn can help a country diversify and reduce the risk of food shortages from climate change." In the literature, the impact of trade opening on GHG emissions are examined under the title of trade and climate change through three principal ways: (i) scale effect, i.e., impact of the expansion of economic activity from trade openness on emissions, (ii) composition effect, i.e., effect of trade openness on the country's production structure via relative prices and the consequence of this on emissions, (iii) technique effect, i.e., the improvements in the production methods and the consequence of this on emissions.

For developing countries, climate change is of highest economic importance as a high ratio of the population is employed in the agricultural sector. Such a dependence renders agricultural trade and hence economic conditions more vulnerable. In this study, the country group to be analyzed are the Middle East and North African (MENA) countries that have oil as the key economic industry which theoretically alleviates the economic vulnerabilities resulting from climate change.

The literature on the impacts of climate change is enormous. Some of them are as follows. The effects are generally investigated for income, GDP, agricultural productivity. Gallup et al. (1998) focus on the relationship between geography and macroeconomic growth and state that the direct role of geography on productivity have four major areas: transport costs, human health, agricultural productivity, and proximity and ownership of natural resources. He explains that climate change have large effects on income through transport costs, disease burdens and agricultural productivity. Dell et al. (2009) examine the impact of climate variables - mean temperature and mean precipitation levels- on labor income and GDP per capitalizing sub-national data for 12 countries in the Western Hemisphere for the averaged time between 1950 and 2000. OLS analyses reflect negative impact of temperature. Holst et al. (2013) examine the effect of regional climate change on grain production in China using temperature and precipitation. Empirical findings suggest significant negative impact on grain output in China as a whole following a rise in temperature. Heal and Park (2013) using fixed effects panel for the time span of 1950-2005 for 134 countries suggest that hotter-than- average years are associated with lower output per capita for countries in hot climates and higher output per capita for countries in cold ones.

Compared to the large literature on the impacts of climate change, there are relatively less number of studies on the impact of climate change on agricultural trade. Ludi et al. (2007) argues that the impact of climate change on international trade is not clear but what is clear is that climate change will have effect on prices. They argue that price of imports can be affected directly and indirectly by climate change. If the increased production in the areas that benefit from climate change is lower than the decline in the areas that will lose from climate change, global supply will decline and agricultural prices rise. This is the direct effect. As for the indirect effect, it is argued that if the concern over climate change leads to a decline in oil use but rise to the use of biofuels, which are obtained from biological products, this will divert agricultural resources away from food production, leading to the rise in agricultural prices again. Finally, they argue that "due to the uncertainties of climate change impacts on agriculture, and also of the socio-economic development paths in the North and the South and related policy responses, large 
uncertainties remain with respect to what impacts climate change might have on agricultural production and international trade" Ludi et al. $(2007,15)$. Regarding the impact of climate on international trade, Li et al. (2015) observe that there are significant effects of climate shocks in on exports but impact is very minor on imports for China.

The rest of the paper is organized as follows. Section 2 represents the model and the relevant dataset in details. Section 3 explains empirical findings. The last section concludes the paper.

\section{Methodology}

\subsection{Model}

To examine the impact of climate change on agricultural trade, we estimate the following equation model:

$$
\text { agrtrade }_{i t}=\mu+\alpha_{i}+\delta_{t}+\beta_{1} \text { growt }_{i t}+\beta_{2} \text { oil }_{i t}+\beta_{3} \text { temp }_{i t}+\beta_{3} \text { prec }_{i t}+u_{i t}
$$

where agrtrade $_{i t}$ is used in six different forms: natural logarithm of trade volume, trade volume as a ratio of GDP, natural logarithm of import, import as a ratio of GDP, natural logarithm of export, export as a ratio of GDP. oil $l_{i t}$ is used in two different forms: natural logarithm of oil consumption and oil consumption per capita. $\mu$ presents constant coefficient, $\alpha_{i}$ presents country fixed effects and $\delta_{t}$ presents fixed effects (time dummy) in time period. Time dummy measures the time effects that are unrelated to the fundamentals of the model, i.e., to the fixed effects.

The impact of climate change is observable in the long run. In that case, dynamic analyses (Note 2) will be useless and the empirical technique to employ should have long run, i.e., static aspect. For the long run aspect, we decided to employ fixed effect model for regression analyses.

\subsection{Dataset}

The analysis is based on 11 MENA countries for 1980-2013 period: Algeria, Bahrain, Egypt, Iran, Israel, Jordan, Morocco, Saudi Arabia, Tunisia, Turkey, United Arab Emirates. Annual datasets regarding climate change is obtained from Climatic Research Unit (CRU) at the University of East Anglia. Data on oil consumption are from Energy Information Administration (EIA), agricultural trade data are from World Trade Organization (WTO). Other dataset are obtained from World Development Indicators database (WDI). Annual precipitation is $\mathrm{mm} / \mathrm{month}$ based and monthly averaged. Annual temperature is degrees Celsius based and monthly averaged. Oil consumption dataset are barrels per day. Free trade agreement dates given in Table 1 are used for trade dummy.

Table 1. List and dates of free trade agreements

\begin{tabular}{|c|c|c|c|}
\hline & European Union ${ }^{(1)}$ & $\mathrm{USA}^{(2)(3)}$ & Other \\
\hline Algeria & AA - 2005, 01 Sep. & & \\
\hline Bahrain & & FTA - 2006, 11 Jan. & $\begin{array}{c}\text { China\&GCC FTA negotiations } \\
\text { since 2004, Jul. }{ }^{(4)}\end{array}$ \\
\hline $\begin{array}{l}\text { Egypt } \\
\text { Iran }\end{array}$ & AA - 2004, 01 Jun. & & \\
\hline Israel & AA - 2000, 01 Jun. & FTA - 1985, 19 Aug. & \\
\hline Jordan & AA - 2002, 01 May & FTA - 2001, 17 Dec. & \\
\hline Morocco & AA - 2000, 01 Mar. & FTA - 2006, 01 Jan. & \\
\hline Saudi Arabia & & & $\begin{array}{l}\text { China\&GCC FTA negotiations } \\
\text { since 2004, Jul. }{ }^{(4)}\end{array}$ \\
\hline Tunisia & AA - 1998, 01 Mar. & & Korea FTA - 2013, 1 May ${ }^{(5)}$ \\
\hline UAE & & $\begin{array}{l}\text { FTA negotiations since } 2004, \\
15 \text { Nov. }\end{array}$ & $\begin{array}{l}\text { China\&GCC FTA negotiations } \\
\text { since } 2004, \text { Jul. }^{(4)}\end{array}$ \\
\hline \multicolumn{4}{|c|}{ Sources: ${ }^{(1)}$ http://ec.europa.eu/trade/policy/countries-and-regions/agreements/\#_mediterranean. } \\
\hline \multicolumn{4}{|c|}{ (2) $\mathrm{https} / / /$ ustr.gov/trade-agreements/free-trade-agreements } \\
\hline \multicolumn{4}{|c|}{${ }^{(3)}$ http://wits.worldbank.org/gptad/library.aspx } \\
\hline${ }^{(4)} \mathrm{http}: / / \mathrm{fta} \cdot \mathrm{mof}$ & gov.cn/topic/engcc.sl & & \\
\hline
\end{tabular}

Notes: AA, CU, FTA denotes Association Agreement, Customs Union, Free Trade Agreement, successively. Dates above are bilateral or regional agreements in force. 


\section{Empirical Findings}

As explained above, the unprecedented rise in the GHG emissions has led to a significant rise in global temperatures, especially after the late 1970s. This increase in the temperatures has deteriorating effects on agricultural production for the low-latitude region economies whereas for mid- and high-latitude region economies, it may be beneficial up to a certain degree of $3^{\circ} \mathrm{C}$. Above that degree, global warming is likely to have negative impact for all region economies (Nyong, 2009). As seen in Figure 1, annual average temperature for MENA countries reflects a rise of around $1.5-2 \%$ from 1980 to 2010. The increase in global temperature is attributed to the GHG emissions. Figure 2 depicts the substantial rise in $\mathrm{CO} 2$ emissions in MENA countries which is the primary GHG (Note 3) emitted through activities such as combustion of fossil fuels (coal, natural gas and oil).

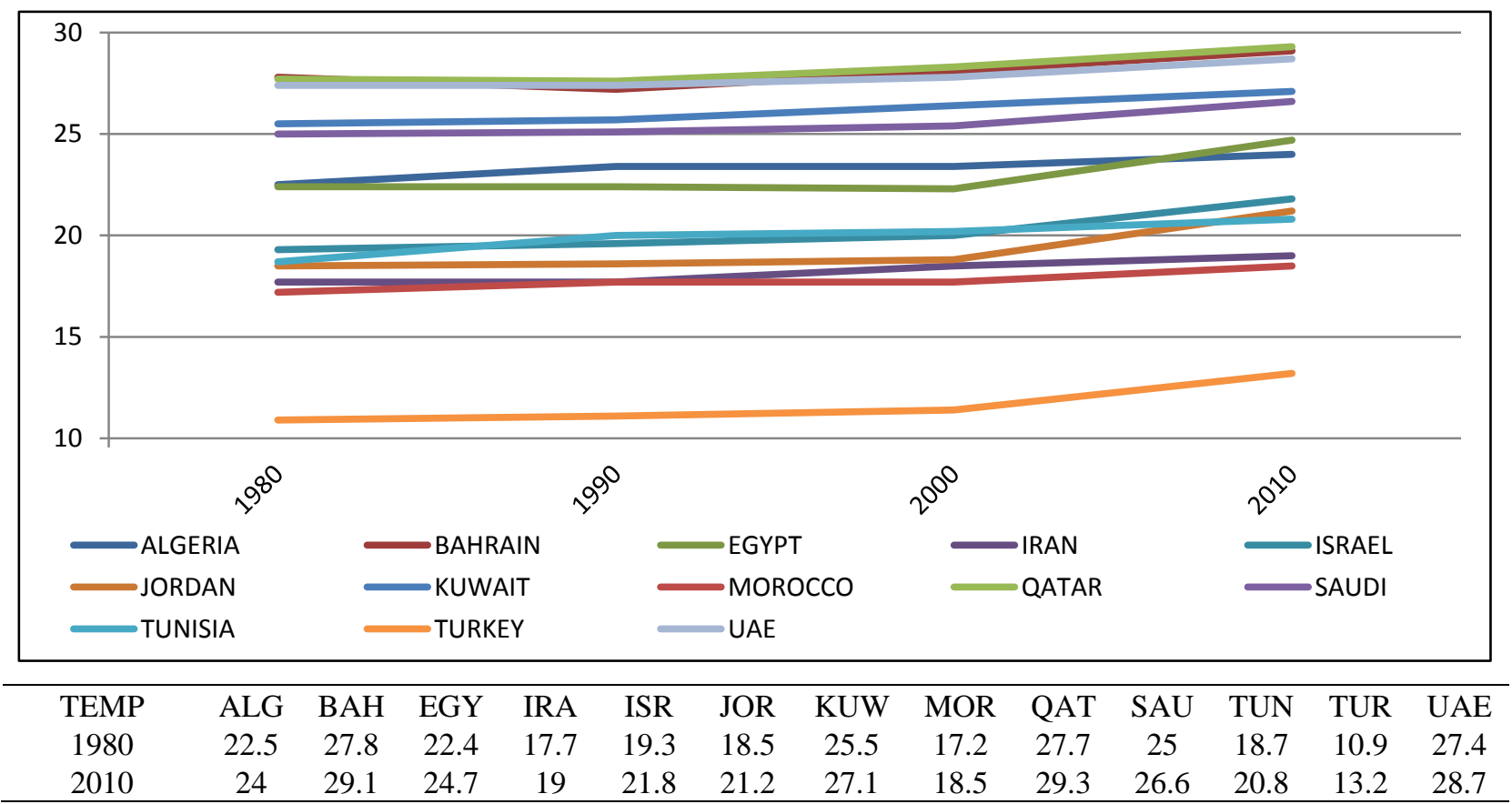

Figure 1. Temperatures (Degrees Celsius)

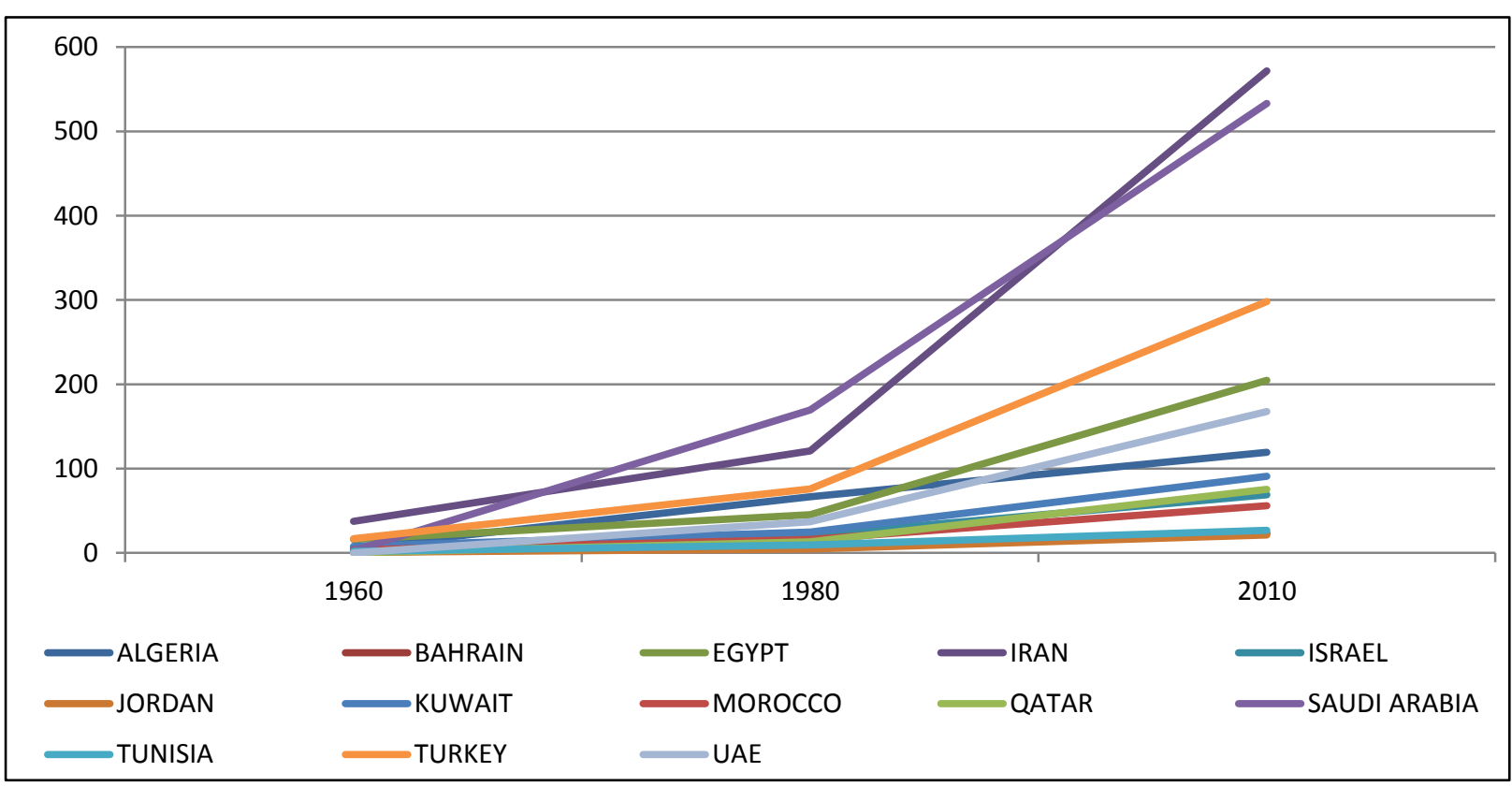

Figure 2. CO2 emissions (kt) (thousand) 
In this paper, we examine 11 MENA countries in which 4 of them (Algeria, Iran, Saudi Arabia and United Arab Emirates) are OPEC countries. Hence, oil production and oil exports constitute a crucial share of their economies. 3 MENA countries, Egypt, Bahrain and Tunisia, are non-OPEC but petroleum comes as the top export product. Egypt is a member of Organization of Arab Petroleum Exporting Countries with the sixth largest oil reserves in Africa. Bahrain's banking and financial services constitute a large share of the total economy. The rest of the countries have non-oil based economies. Israeli economy depends on petroleum imports but produces very high-technology products which renders the economy highly developed. Jordan is among the emerging market economies and has a developed banking sector. Morocco is an important player in the African economy and services sector constitutes more than $60 \%$ of GDP. Finally, Turkey is an emerging country with the services sector of more than $60 \%$ of GDP. The country is among the leading exporters of agricultural producers, textiles and motor vehicles. In short, none of the MENA countries have agricultural production at the center of their economy.

MENA countries are in mid-latitude but these economies are generally not agricultural countries, rather they are importers for cereals as observed in Table 2. Out of 11 MENA countries, 5 are among the world's first 20 largest cereal importers and 4 are among the world's first 20 largest wheat and meslin importers.

Table 2. Cereal and wheat and meslin import values of MENA countries and their world rank

\begin{tabular}{|c|c|c|c|c|c|}
\hline \multicolumn{3}{|c|}{ Cereal Import } & \multicolumn{3}{|c|}{ Wheat and Meslin Import } \\
\hline World Rank & Country & $\begin{array}{l}\text { Trade Value } \\
\text { (million US\$) }\end{array}$ & World Rank & Country & $\begin{array}{l}\text { Trade Value } \\
\text { (million US\$) }\end{array}$ \\
\hline 2 & Saudi Arabia & 4104.74 & 1 & Egypt & 2181.91 \\
\hline 3 & Egypt & 3483.90 & 7 & Algeria & 1251.59 \\
\hline 11 & Iran & 2284.79 & 12 & Morocco & 878.46 \\
\hline 14 & Algeria & 1950.57 & 18 & Turkey & 655.04 \\
\hline 18 & UAE & 1674.09 & 23 & Tunisia & 476.16 \\
\hline 22 & Morocco & 1408.25 & 27 & Saudi Arabia & 400.01 \\
\hline 29 & Turkey & 1056.75 & 28 & Israel & 389.85 \\
\hline 35 & Israel & 792.98 & 34 & Iran & 315.92 \\
\hline 36 & Tunisia & 766.21 & 44 & UAE & 214.46 \\
\hline 44 & Jordan & 429.48 & 61 & Jordan & 110.61 \\
\hline 95 & Bahrain & 103.15 & 87 & Bahrain & 35.93 \\
\hline
\end{tabular}

Source: UN Comtrade Database (http://comtrade.un.org/data/)

Table 3. Fixed effects model for trade volume

\begin{tabular}{lcccccc}
\hline Variables & $(1)$ & $(2)$ & $(3)$ & $(4)$ & $(5)$ & $(6)$ \\
\hline Growth & 0.416 & 0.395 & 0.370 & 0.407 & 0.391 & 0.362 \\
& $(0.289)$ & $(0.278)$ & $(0.275)$ & $(0.289)$ & $(0.278)$ & $(0.275)$ \\
Temp & $-0.103^{* *}$ & $-0.084^{* *}$ & $-0.106^{* *}$ & $-0.103^{* *}$ & $-0.085^{* *}$ & $-0.107^{* *}$ \\
& $(0.044)$ & $(0.042)$ & $(0.042)$ & $(0.044)$ & $(0.042)$ & $(0.042)$ \\
Prec & $6.8 \mathrm{E}-05$ & $1.2 \mathrm{E}-04$ & $1 \mathrm{E}-04$ & $8.5 \mathrm{E}-05$ & & \\
& $(0.000)$ & $(2.4 \mathrm{E}-04)$ & $(2.4 \mathrm{E}-04)$ & $(0.000)$ & & \\
Oilcons & & $0.494^{* *}$ & & & $0.499^{* *}$ & \\
& & $(0.094)$ & & & $(0.097)$ & \\
Oilconscap & & & $-8.208^{* *}$ & & & $-8.137^{* *}$ \\
& & & $(1.417)$ & & & $(1.425)$ \\
Constant & $24.030^{* *}$ & $17.499^{* *}$ & $24.356^{* *}$ & $24.031^{* *}$ & $17.486^{* *}$ & $24.399^{* *}$ \\
& $(0.930)$ & $(1.536)$ & $(0.888)$ & $(0.930)$ & $(1.561)$ & $(0.883)$ \\
DummyTrade & & & & -0.043 & 0.012 & -0.016 \\
& & & & $(0.045)$ & $(0.045)$ & $(0.043)$ \\
Obs & 374 & 374 & 374 & 374 & 374 & 374 \\
\hline
\end{tabular}

Note: Dependent variable is agricultural trade volume. $(*)$ and $(* *)$ denote significancy at $5 \%$ and $10 \%$, successively. Fixed effects model in time and cross section unit. 
Table 4. Fixed effects model for trade volume/GDP

\begin{tabular}{lcccccc}
\hline Variables & $(1)$ & $(2)$ & $(3)$ & $(4)$ & $(5)$ & $(6)$ \\
\hline Growth & $0.040^{*}$ & $0.040^{*}$ & 0.040 & 0.040 & 0.040 & 0.040 \\
& $(0.025)$ & $(0.025)$ & $(0.025)$ & $(0.025)$ & $(0.025)$ & $(0.025)$ \\
Temp & $-0.007^{*}$ & $-0.006^{*}$ & $-0.007^{*}$ & $-0.007^{*}$ & $-0.007^{*}$ & $-0.006^{*}$ \\
& $(0.004)$ & $(0.004)$ & $(0.004)$ & $(0.004)$ & $(0.004)$ & $(0.004)$ \\
Prec & $-4.1 \mathrm{E}-06$ & & & & $-1.3 \mathrm{E}-06$ & \\
& $(2.2 \mathrm{E}-05)$ & & & & $(2.2 \mathrm{E}-05)$ & \\
Oilcons & & $0.020^{*}$ & & & & $0.017^{* *}$ \\
& & $(0.008)$ & & & & $(0.009)$ \\
Oilconscap & & & -0.183 & & & \\
& & & $(0.127)$ & & & \\
Constant & $0.218^{* *}$ & -0.050 & $0.224^{* *}$ & $0.218^{* *}$ & $0.218^{* *}$ & -0.013 \\
& $(0.007)$ & $(0.135)$ & $(0.079)$ & $(0.080)$ & $(0.080)$ & $(0.138)$ \\
DummyTrade & & & & $-0.007^{*}$ & $-0.007 *$ & -0.005 \\
& & & & $(0.004)$ & $(0.004)$ & $(0.004)$ \\
Obs & 374 & 374 & 374 & 374 & 374 & 374 \\
\hline
\end{tabular}

Table 5. Fixed effects model for imports

\begin{tabular}{lcccccc}
\hline Variables & $(1)$ & $(2)$ & $(3)$ & $(4)$ & $(5)$ & $(6)$ \\
\hline Growth & 0.217 & 0.201 & 0.164 & 0.217 & 0.209 & 0.171 \\
& $(0.378)$ & $(0.374)$ & $(0.366)$ & $(0.378)$ & $(0.374)$ & $(0.366)$ \\
Temp & $-0.155^{* *}$ & $-0.143^{* *}$ & $-0.160^{* *}$ & $-0.155^{* *}$ & $-0.142^{* *}$ & $-0.160^{* *}$ \\
& $(0.057)$ & $(0.057)$ & $(0.055)$ & $(0.057)$ & $(0.057)$ & $(0.056)$ \\
Prec & $1.8 \mathrm{E}-05$ & & & $3.6 \mathrm{E}-05$ & \\
& $(0.000)$ & & & $(3.3 \mathrm{E}-04)$ & \\
Oilcons & & $0.324^{* *}$ & & & $0.346^{* *}$ & \\
& & $(0.127)$ & & & $(0.131)$ & \\
Oilconscap & & & $-8.929^{* *}$ & & & $-9.036^{* *}$ \\
& & & $(1.884)$ & & & $(1.896)$ \\
Constant & $24.799^{* *}$ & $20.525^{* *}$ & $25.176^{* *}$ & $24.806^{* *}$ & $20.228^{* *}$ & $25.174^{* *}$ \\
& $(1.219)$ & $(2.063)$ & $(1.173)$ & $(1.210)$ & $(2.118)$ & $(1.175$ \\
DummyTrade & & & & 0.002 & 0.040 & 0.031 \\
& & & & & & \\
Obs & 374 & 374 & 374 & 374 & $(0.060)$ & $(0.057)$ \\
\hline
\end{tabular}

Table 6. Fixed effects model for imports/GDP

\begin{tabular}{lcccccc}
\hline Variables & $(1)$ & $(2)$ & $(3)$ & $(4)$ & $(5)$ & $(6)$ \\
\hline Growth & 0.019 & 0.018 & 0.018 & 0.017 & 0.017 & 0.016 \\
& $(0.021)$ & $(0.021)$ & $(0.021)$ & $(0.021)$ & $(0.021)$ & $(0.021)$ \\
Temp & $-0.006^{* *}$ & -0.005 & $-0.006^{*}$ & $-0.006^{*}$ & $-0.005^{*}$ & $-0.006^{*}$ \\
& $(0.003)$ & $(0.003)$ & $(0.003)$ & $(0.003)$ & $(0.003)$ & $(0.003)$ \\
Prec & $-7.6 \mathrm{E}-06$ & & & $-5.0 \mathrm{E}-06$ & $-4.5 \mathrm{E}-06$ & $-4.6 \mathrm{E}-06$ \\
& $(1.9 \mathrm{E}-05)$ & & & $(1.8 \mathrm{E}-05)$ & $(1.8 \mathrm{E}-05)$ & $(1.8 \mathrm{E}-05)$ \\
Oilcons & & $0.012^{*}$ & & & 0.009 & \\
& & $(0.007)$ & & & $(0.007)$ & \\
Oilconscap & & & -0.162 & & & -0.140 \\
& & & $(0.110)$ & & & $(0.110)$ \\
Constant & $0.170^{* *}$ & $0.006^{* *}$ & $0.174^{* *}$ & $0.170^{* *}$ & 0.047 & $0.176^{* *}$ \\
& $(0.069)$ & $(0.117)$ & $(0.068)$ & $(0.068)$ & $(0.120)$ & $(0.068)$ \\
DummyTrade & & & & $-0.006^{* *}$ & $-0.005^{*}$ & $-0.006^{*}$ \\
& & & & $(0.003)$ & $(0.003)$ & $(0.003)$ \\
Obs & 374 & 374 & 374 & 374 & 374 & 374 \\
\hline
\end{tabular}


Fixed effect models for MENA countries reflect that climate change in the form of increasing temperature has negative effect on agricultural import, agricultural trade volume and the ratio of these two to GDP, given in Tables 3 to 6. However, temperature does not have a significant impact on agricultural trade variables. Theoretically, a rise in productivity may lead to a rise in trade. On the other hand, according to Cline (2007), developing countries that are in need of increasing agricultural imports so as to adapt changes in climate conditions would have a constraint from lower purchasing power. MENA countries do not have limited purchasing power, in general. It is also obvious that there is no productivity increase in agricultural products since imports are decreasing while the world temperature is rising. Hence, the decline in the imports of MENA countries can be attributed to the loss of agricultural productivity in the import destinations. Insignificancy of export can be explained by the fact that these economies are non-agriculture based countries. MENA region is generally non-productive (except for Turkey) as the precipitation is relatively low compared to other regions. Hence a rise in temperature may not have beneficial effect in agriculture as it is argued to be in mid- to high-latitude regions either because the annual precipitation is not sufficient or these economies do not want to have agriculture in the center of their production facilities. Given Figure 3, it is observed that annual precipitation does not reveal a rising trend within a time span of more than 30 years. The second climate change indicator, precipitation does not have a significant impact on agricultural trade variables.

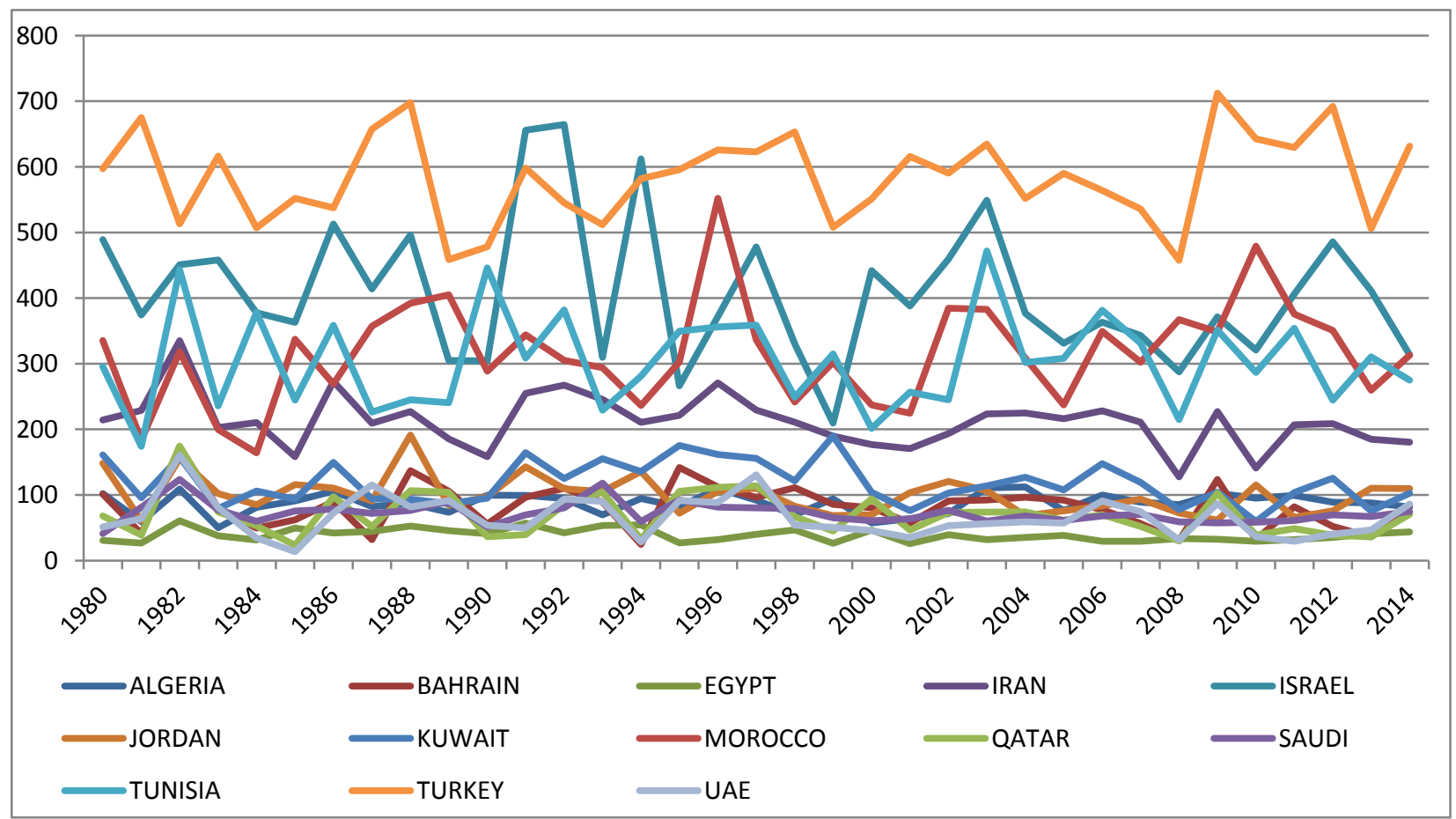

Figure 3. Average precipitation in depth (mm per month)

In order to investigate whether there is decline in the productivity in the agricultural sector, cereal production is examined as it is one of the most vital agricultural products. Figure 5 depicts the historical graph of cereal yield and cereal production. It is observed that cereal yield per hectare, (or the productivity in cereal production), reflects a rise but the trend is getting lower than cereal production. In order to have a better look at productivity in cereal production, we check production per capita for cereal given in Figure 6. As seen in Table 7, world cereal production per capita reflects a decline in the trend in year 1999 which is investigated using Perron (1997) unit root test with structural breaks for the period 1961-2013. Desmet and Rossi-Hansberng (2015) explain that rise in mean temperature and its effect on productivity is the most direct expressions of climate change. Consistent to this, we can argue that there is a decline in the productivity of cereal production. 


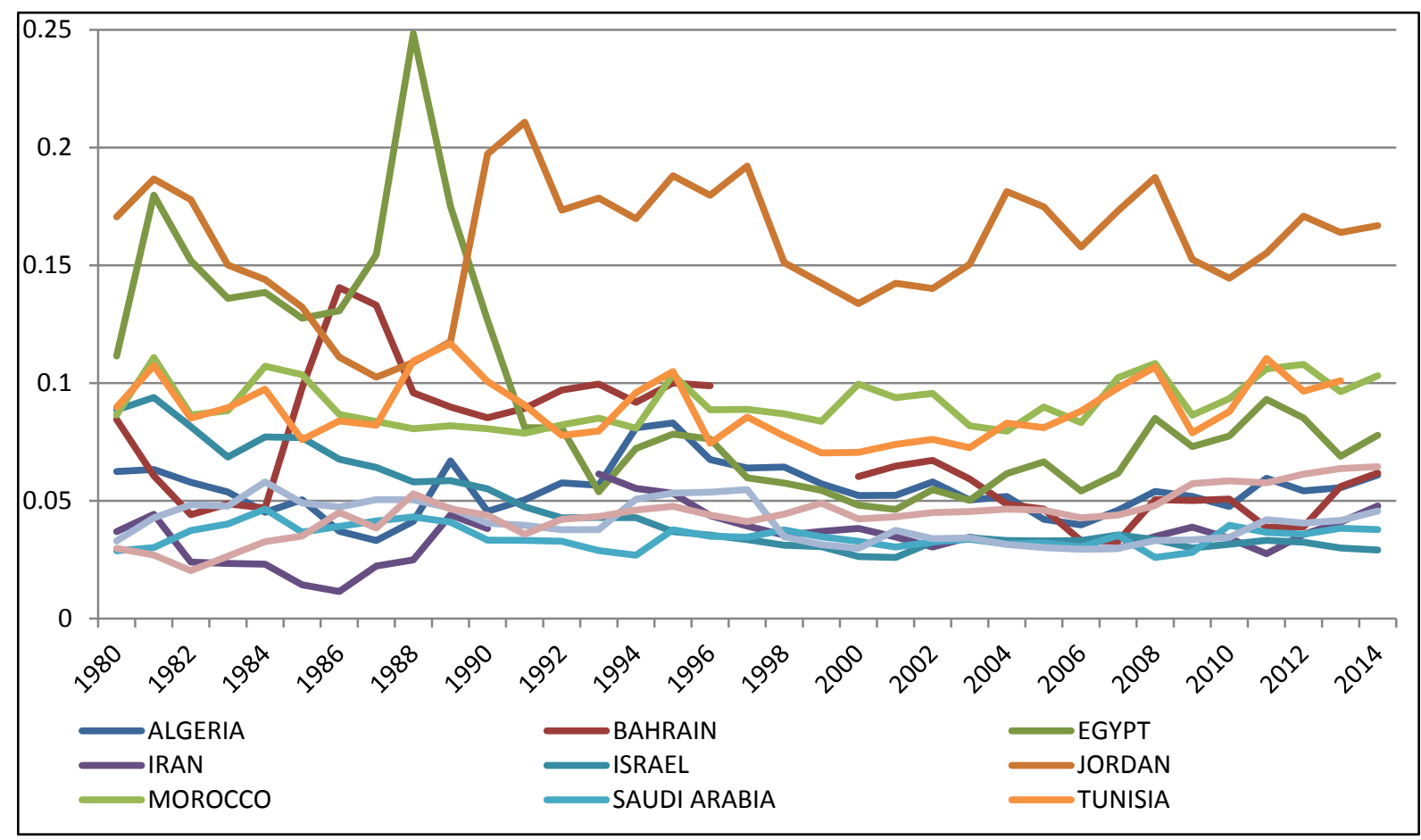

Figure 4. Agricultural trade (\% GDP)

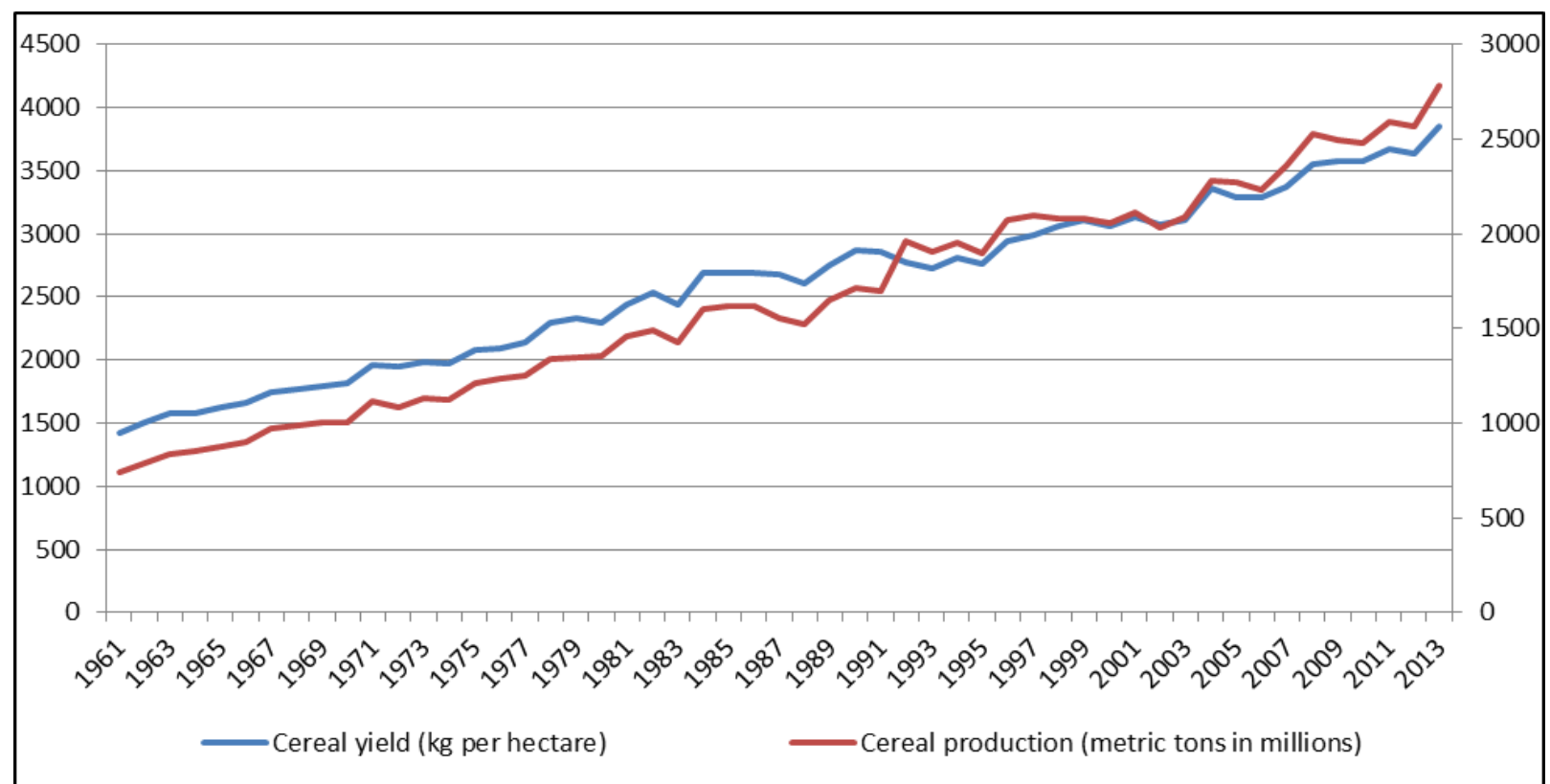

Figure 5. World cereal production and yield

Source: World Bank 


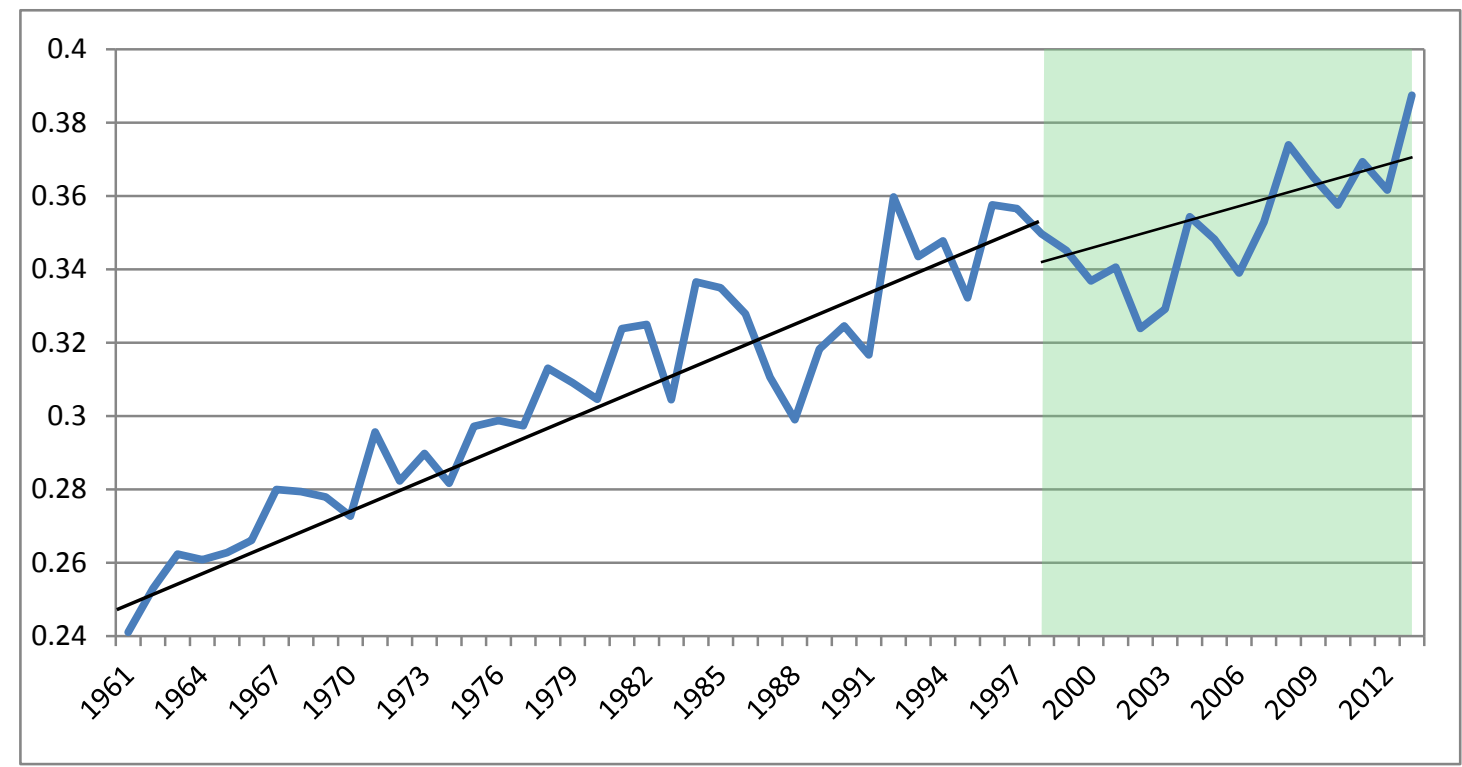

Figure 6. World cereal production per capita

Source: World Bank

Table 7. Perron (1997) Unit Root test for data with structural breaks

\begin{tabular}{lc}
\hline Sample:1961 2013 & \\
Chosen break point: 1999 & t-Statistic \\
& -6.186560 \\
Test statistics & -6.32 \\
$1 \%$ critical value: & -5.59 \\
5\% critical value: & -5.29 \\
$10 \%$ critical value: &
\end{tabular}

Note: Null hypothesis is presence of a unit root with a structural break in both the intercept and trend. Chosen lag length is 0 out of a maximum lags of 4 .

Oil consumption has positive impact on agricultural trade variables whereas oil consumption per capita has negative impact on import and trade volume. Oil consumption may reflect the rise in production facilities leading to a rise in agricultural import and export. However, the negative impact of per capita oil consumption may be attributed to the case that rising oil consumption after a threshold level, i.e., a rise in per capita level requires a higher increase than the rise in aggregate level, may harm environment and productivity.

It is observed that the trade agreement dummy has negative and significant effect on agricultural trade volume as a ratio of GDP and agricultural import as a ratio of GDP, given in Tables 4 and 7, successively. Taylor (2002) argues that trade liberalization has optimistic and pessimistic scenarios for rural economies in less developed countries. Trade reforms may create new markets for goods and factors that are supplied by rural households. On the other hand, it can hamper the trade of previously protected markets by abolishing barriers against trade. A World Bank (2010) report on the trade integration in the MENA region explains that MENA region is relatively less integrated with global markets with the exception of oil market. MENA countries have constructed a regional free trade area (PAFTA) which reduces tariff barriers for the member countries. Yet, there are non-tariff barriers that continue to hamper fully-functioning trade liberalization. Moreover, regional trade constitutes less than $10 \%$ of total trade for most Arab countries. According to trade theories, reducing import tariffs and non-tariff barriers will lower the price of goods and increase the number of accessible goods which create competitiveness. It is observed that trade 
agreements have negative impact on import as a ratio of GDP and trade volume as a ratio of GDP. There is no significant impact on import and trade volume. Hence, it can be argued that trade agreements increase their GDP which is a general result of free trade theoretically and that even if the agricultural import is not significantly decreasing, it reflects a decline as ratio of GDP.

Last but not least, growth rate has a positive impact on agricultural exports as value and as ratio of GDP. In other words, economic growth contributes to agricultural exports in MENA countries. Given Figure 7, it is observed that cereal production is rapidly increasing in MENA countries. The MENA country with lowest cereal production is Jordan by 2013. Following that UAE comes with a slightly higher figure but UAE did not produce cereal until 1977. All MENA countries reflect a positive trend in cereal production. Hence, the positive sign of growth rate on agricultural exports can be attributed to the rise in agricultural production.

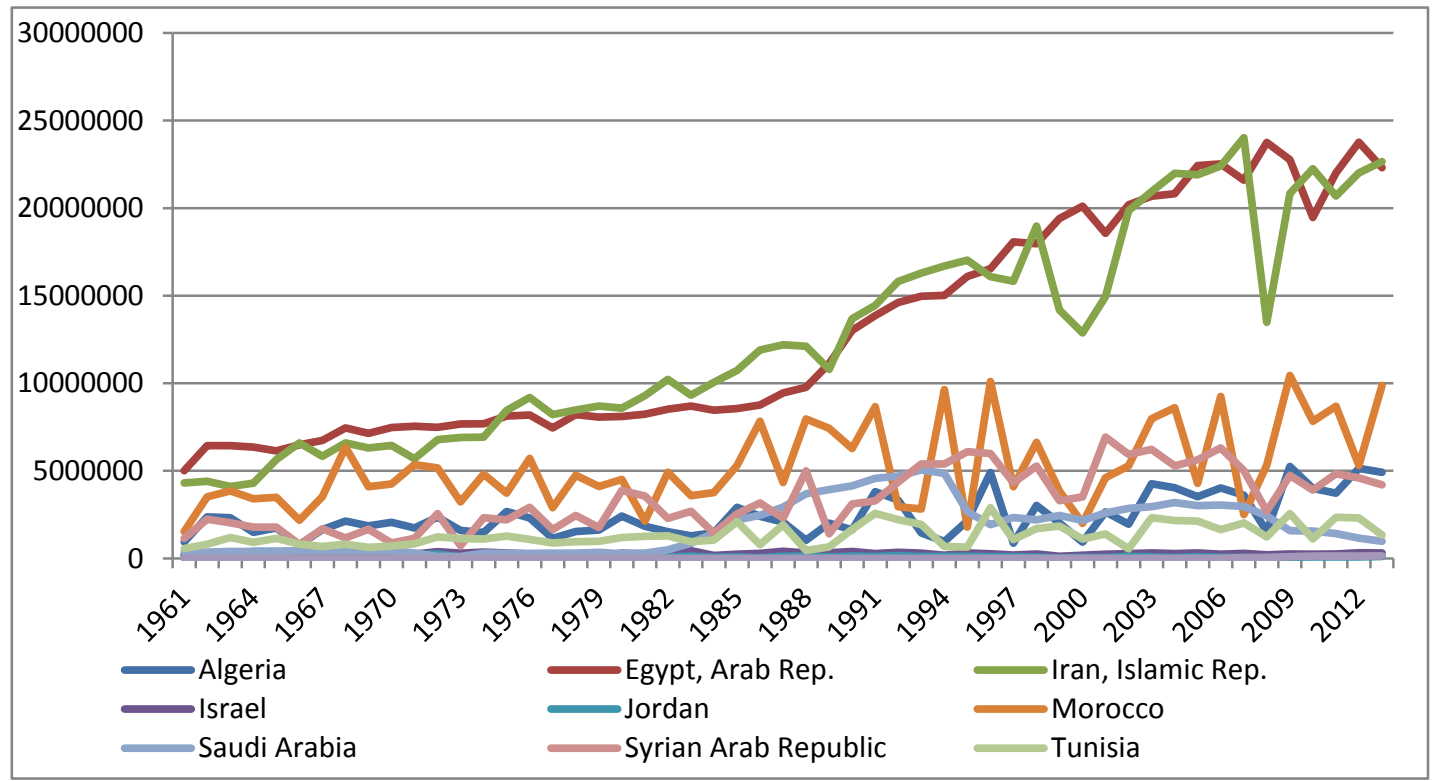

Figure 7. Cereal production (metric tons) in MENA countries

\section{Conclusion}

Climate change has been a very serious challenge for both ecological and economic systems and poses significant threats for several aspects of life and livelihood. Agricultural trade is one of the most vulnerable economic activities that is expected to be affected by climate change, especially in the developing countries. In this paper, agricultural trade variables in the form import, export and trade volume and their ratios to GDP are examined for climate change variables. For climate change, we employ annual average temperature and precipitation levels. There exists a vast literature on the impacts of climate change, but the effects on agricultural trade is not sufficiently examined. Moreover, differently from the literature, we focused on MENA countries which is a specific region where the main economic activities depend on oil production, except for Turkey, Morocco, Jordan and Israel.

Using panel data for the period 1980-2013, we observe that climate change in the form of temperature has a negative impact on agricultural imports. The other climate change indicator, precipitation level, does not reflect any significant impact on any of the agricultural trade variables in the model.

In the climate change analysis, it is argued that rise in temperature is likely to have positive impact on mid- to high-latitude region economies whereas the effect turns out to be deteriorating for low-latitude region countries since a relatively warmer weather contributes to agricultural productivity in colder areas, but the effect is like drought for already warm areas (IPCC, 2014). MENA countries are in mid-latitude region but it is observed that the effect of climate change is deteriorating. The model employed in this paper concluded that, neither temperature nor precipitation have significant impacts on agricultural trade variables. Oil consumption, on the other hand, has positive impact on agricultural trade variables whereas oil consumption per capita has negative impact on import and trade volume. The trade agreement dummy has negative and significant effect on agricultural trade volume as a ratio 
of GDP and agricultural import as a ratio of GDP. Finally, growth rate has a positive impact on agricultural exports as value and as ratio of GDP. According to the models based on the available data, it is not directly observed that global warming is directly influencing agricultural production and trade. However, the region faces the risk of falling agricultural yields as temperatures increase further and precipitation rates fall with their current increasing trends.

\section{References}

Burgess, R., Deschenes, O., Donaldson, D., \& Greenstone, M. (2013). The unequal effects of weather and climate change: Evidence from mortality in India. Unpublished working paper.

Chengzheng L, Xiang, X., \& Gu, H. (2015). Climate shocks and international trade: Evidence from China. Economics Letters, 135, 55-57.

Cline, W. R. (2007). Global Warming and Agriculture: Impact Estimates by Country. Peterson Institute for International Economics, Washington, DC.

Cline, W. R. (2008, March). Global Warming and Agriculture. Finance \& Development, 23-27.

Desmet, K., \& Rossi-Hansberg, E. (2015). On the spatial economic impact of global warming. Journal of Urban Economics, 88, 16-37.

Gallup, J. L., Sachs, J. D., \& Mellinger, A. D. (1998). Geography and Economic Development. NBER Working Paper No. 6849. Retrieved from http://www.nber.org/papers/w6849.

Hansen, J., Ruedy, R., Sato, M., \& Lo, K. (2010). Global surface temperature change. Reviews of Geophysics, 48(4).

Heal, G., \& Park, J. (2013). Feeling The Heat: Temperature, Physiology \& The Wealth of Nations. NBER Working Paper 19725. Retrieved from http://www.nber.org/papers/w19725

Holst, R., Yu, X., \& Grün, C. (2013). Climate Change, Risk and Grain Yields in China. Journal of Integrative Agriculture, 12(7), 1279-1291.

IPCC. (2014). Climate Change 2014: Synthesis Report. Contribution of Working Groups I, II and III to the Fifth Assessment Report of the Intergovernmental Panel on Climate Change [Core Writing Team, R.K. Pachauri and L.A. Meyer (eds.)]. IPCC, Geneva, Switzerland.

IPCC. (2015). Adoption of the Paris Agreement. Proposal by the President. Retrieved from http://unfccc.int/resource/docs/2015/cop21/eng/109r01.pdf

Jones, P.D. and Harris, I. (2008), Climatic Research Unit (CRU) time-series datasets of variations in climate with variations in other phenomena. NCAS British Atmospheric Data Centre. Retrieved from http://catalogue.ceda.ac.uk/uuid/3f8944800cc48e1cbc29a5ee12d8542d

Ludi, E., Stevens, C., Peskett, L., \& Cabral, L. (2007). Climate change and agriculture: Agricultural trade, markets and investment. Overseas Development Institute, London. http://www.odi.org/sites/odi.org.uk/files/odi-assets/publications-opinion-files/1884.pdf, Accessed 14 December 2015.

Nyong, A. (2009). Climate Change Impacts in the Developing World: Implications for Sustainable Development. In Climate Change and Global Poverty: A Billion Lives in the Balance?, Brookings Institution Press, Washington, DC.

Nyong, A. O. (2008). Climate Change, Agriculture and Trade: Implications for Sustainable Development. A Background Paper prepared for the International Centre for Trade and Sustainable Development (ICTSD) and the session titled Agriculture, Climate Change and Sustainable Development at The Future of Agriculture: A Global Dialogue amongst Stakeholders. $\quad$ Retrieved from http://www.agritrade.org/events/documents/paper_anthony_nyong_barcelona08.pdf, Accessed 14 December 2015

Tamiotti, L., The, R., Kulaçoğlu, V., Olhoff, A., Simmons, B., \& Abaza, H. (2009). Trade and Climate Change. WTO-UNEP Report, World Trade Organization Publications.

US Environmental Protection Agency. (2015). Retrieved from http://www3.epa.gov/climatechange/ghgemissions/global.html

Waldinger, M. (2015). The effects of climate change on internal and international migration: implications for developing countries. Centre for Climate Change Economics and Policy Working Paper No. 217. 
World Bank. (2010). Trade Integration in the Middle East and North Africa report of World Bank. Retrieved from http://go.worldbank.org/IZ7F77A120

\section{Notes}

Note 1. See UNFCCC (2015) for further details of the Paris Agreement.

Note 2. To control for short run effects of climate change on agricultural trade, dynamic panel GMM analyses are also checked and the impact is observed to be insignificant as expected.

Note 3. $\mathrm{CO} 2$ constitutes $75 \%$ of total GHG emissions via fossil fuel, industrial processes, forestry and other land use; second gas is methane of around 18\% (IPCC, 2015a).

\section{Appendix}

Table A1. Descriptive statistics

\begin{tabular}{lccccccccccc}
\hline & Vol & Volgdp & Im & Imgdp & Ex & Exgdp & Growth & $\begin{array}{c}\text { Temp } \\
\left({ }^{\circ} \mathrm{C}\right)\end{array}$ & $\begin{array}{c}\text { Prec } \\
(\mathrm{mm} / \mathrm{mon} .)\end{array}$ & Oilcons & Oilconscap \\
\hline Mean & 21.89 & 0.07 & 3620 & 0.05 & 1500 & 0.02 & 0.039 & 21.078 & 206.882 & 12.373 & 0.032 \\
Max & 24.26 & 0.25 & 24900 & 0.22 & 17400 & 0.06 & 0.239 & 29.100 & 712.400 & 14.889 & 0.158 \\
Min & 18.90 & 0.01 & 158 & 0.01 & 2.68 & 0.00 & -0.150 & 9.700 & 13.400 & 9.641 & 0.004 \\
St.Dev. & 1.00 & 0.04 & 3900 & 0.03 & 2230 & 0.01 & 0.046 & 4.633 & 177.122 & 1.217 & 0.035 \\
Skew. & -0.25 & 1.42 & 2.391 & 1.60 & 3.549 & 0.62 & -0.229 & -0.342 & 1.057 & -0.163 & 1.806 \\
Kurt. & 3.12 & 4.75 & 9.589 & 5.81 & 19.771 & 2.29 & 6.449 & 2.660 & 3.073 & 2.421 & 5.584 \\
Obs. & 374 & 374 & 374 & 374 & 374 & 374 & 374 & 374 & 374 & 374 & 374 \\
\hline
\end{tabular}

Note: Oilcons is in natural logarithmic form. Mean, maximum, minimum and standard deviation for Im and Ex are in millions.

Table A2. Fixed effects model for exports

\begin{tabular}{lcccccc}
\hline Variables & $(1)$ & $(2)$ & $(3)$ & $(4)$ & $(5)$ & $(6)$ \\
\hline Growth & $1.865^{* *}$ & $1.811^{* *}$ & $1.864^{* *}$ & $1.842^{* *}$ & $1.816^{* *}$ & $1.836^{* *}$ \\
& $(0.579)$ & $(0.537)$ & $(0.578)$ & $(0.579)$ & $(0.539)$ & $(0.579)$ \\
Temp & 0.016 & 0.069 & 0.017 & 0.018 & 0.069 & 0.017 \\
& $(0.088)$ & $(0.082)$ & $(0.088)$ & $(0.088)$ & $(0.082)$ & $(0.088)$ \\
Prec & $-1.6 \mathrm{E}-04$ & & & $-1.2 \mathrm{E}-04$ & $-4.9 \mathrm{E}-05$ & $-1.2 \mathrm{E}-04$ \\
& $(5.1 \mathrm{E}-04)$ & & & $(5.1 \mathrm{E}-04)$ & $(4.7 \mathrm{E}-04)$ & $(5.1 \mathrm{E}-04)$ \\
Oilcons & & $1.326^{* *}$ & & & $1.344^{* *}$ & \\
& & $(0.182)$ & & & $(0.188)$ & \\
Oilconscap & & & -1.727 & & & -1.345 \\
& & & $(2.978)$ & & & $(2.997)$ \\
Constant & $19.827^{* *}$ & 2.270 & $19.828^{* *}$ & $19.830^{* *}$ & 2.055 & $19.883 * *$ \\
& $(1.864)$ & $(2.958)$ & $(1.855)$ & $(1.862)$ & $(3.038)$ & $(1.869)$ \\
DummyTrade & & & & -0.110 & 0.035 & -0.106 \\
& & & & $(0.090)$ & $(0.087)$ & $(0.091)$ \\
Obs & 374 & 374 & 374 & 374 & 374 & 374 \\
\hline
\end{tabular}


Table A3. Fixed effects model for exports/GDP

\begin{tabular}{lcccccc}
\hline Variables & $(1)$ & $(2)$ & $(3)$ & $(4)$ & $(5)$ & $(6)$ \\
\hline Growth & $0.018^{* *}$ & $0.018^{* *}$ & $0.018^{* *}$ & $0.018^{* *}$ & $0.018^{* *}$ & $0.018^{* *}$ \\
& $(0.009)$ & $(0.009)$ & $(0.009)$ & $(0.009)$ & $(0.009)$ & $(0.009)$ \\
Temp & $-5.3 \mathrm{E}-03$ & $-1.5 \mathrm{E}-04$ & -0.001 & -0.001 & -0.001 & -0.001 \\
& $(0.001)$ & $(1.3 \mathrm{E}-03)$ & $(0.001)$ & $(0.001)$ & $(0.001)$ & $(0.001)$ \\
Prec & $1.3 \mathrm{E}-06$ & $2.3 \mathrm{E}-06$ & $1.5 \mathrm{E}-06$ & $1.8 \mathrm{E}-06$ & $2.3 \mathrm{E}-06$ & $1.8 \mathrm{E}-06$ \\
& $(7.5 \mathrm{E}-06)$ & $(7.4 \mathrm{E}-06)$ & $(7.5 \mathrm{E}-06)$ & $(7.6 \mathrm{E}-06)$ & $(7.5 \mathrm{E}-06)$ & $(7.6 \mathrm{E}-06)$ \\
Oilcons & & $0.010^{* *}$ & & & $0.010^{* *}$ & \\
& & $(0.003)$ & & & $(0.003)$ & \\
Oilconscap & & & -0.020 & & & -0.017 \\
& & & $(0.045)$ & & & $(0.045)$ \\
Constant & 0.029 & $-0.098^{* *}$ & 0.030 & 0.030 & $-0.098^{* *}$ & 0.029 \\
& $(0.028)$ & $(0.047)$ & $(0.028)$ & $(0.028)$ & $(0.048)$ & $(0.028)$ \\
DummyTrade & & & & $-9.8 \mathrm{E}-04$ & $6.2 \mathrm{E}-05$ & $-9.2 \mathrm{E}-04$ \\
& & & & $(1.5 \mathrm{E}-03)$ & $(1.3 \mathrm{E}-03)$ & $(1.4 \mathrm{E}-03)$ \\
Obs & 374 & 374 & 374 & 374 & 374 & 374 \\
\hline
\end{tabular}

Table A3. MENA top exports and import goods and destinations (Values in 2013)

\begin{tabular}{|c|c|c|c|c|}
\hline & Top Exports & $\begin{array}{l}\text { Top Exports } \\
\text { Destinations }\end{array}$ & Top Imports & $\begin{array}{l}\text { Top Imports } \\
\text { Destinations }\end{array}$ \\
\hline Algeria & $\begin{array}{l}\text { Crude Petroleum (\$29.5B) } \\
\text { Petroleum Gas (\$28.3B) } \\
\text { Refined Petroleum (\$9.4B) }\end{array}$ & $\begin{array}{l}\text { Spain }(\$ 11.4 \mathrm{~B}) \\
\text { Italy }(\$ 7.88 \mathrm{~B}) \\
\mathrm{UK}(\$ 6.65 \mathrm{~B})\end{array}$ & $\begin{array}{c}\text { Cars }(\$ 4.02 \mathrm{~B}) \\
\text { Refined Petroleum } \\
(\$ 3.62 \mathrm{~B}) \\
\text { Delivery Trucks }(\$ 2.19 \mathrm{~B})\end{array}$ & $\begin{array}{l}\text { France }(\$ 7.08 \mathrm{~B}) \\
\text { China }(\$ 6.76 \mathrm{~B}) \\
\text { Italy }(\$ 5.78 \mathrm{~B})\end{array}$ \\
\hline Bahrain & $\begin{array}{c}\text { Refined Petroleum }(\$ 4.23 \mathrm{~B}) \\
\text { Raw Aluminium }(\$ 809 \mathrm{M}) \\
\text { Aluminium Bars }(\$ 421 \mathrm{M})\end{array}$ & $\begin{array}{l}\text { Saudi Arabia } \\
\qquad(\$ 1.67 \mathrm{~B}) \\
\text { US }(\$ 597 \mathrm{M}) \\
\text { Korea }(\$ 561 \mathrm{M})\end{array}$ & $\begin{array}{c}\text { Cars }(\$ 1.2 \mathrm{~B}) \\
\text { Tug Boats }(\$ 357 \mathrm{M}) \\
\text { Iron Ore }(\$ 307 \mathrm{M})\end{array}$ & $\begin{array}{l}\text { Saudi Arabia } \\
\qquad(\$ 1.55 \mathrm{~B}) \\
\text { China }(\$ 1.24 \mathrm{~B}) \\
\text { Japan }(\$ 754 \mathrm{M})\end{array}$ \\
\hline Egypt & $\begin{array}{l}\text { Crude Petroleum (\$6.69B) } \\
\text { Petroleum Gas }(\$ 2.34 \mathrm{~B}) \\
\text { Refined Petroleum }(\$ 2.3 \mathrm{~B})\end{array}$ & $\begin{array}{l}\text { Italy }(\$ 2.74 \mathrm{~B}) \\
\text { India }(\$ 2.41 \mathrm{~B}) \\
\text { Saudi Arabia } \\
\quad(\$ 2.25 \mathrm{~B})\end{array}$ & $\begin{array}{c}\text { Refined Petroleum } \\
(\$ 6.56 \mathrm{~B}) \\
\text { Wheat }(\$ 2.52 \mathrm{~B}) \\
\text { Crude Petroleum }(\$ 1.96 \mathrm{~B})\end{array}$ & $\begin{array}{c}\text { China }(\$ 7.69 \mathrm{~B}) \\
\text { US }(\$ 5.15 \mathrm{~B}) \\
\text { Italy }(\$ 3.8 \mathrm{~B})\end{array}$ \\
\hline & Crude Petroleum ( $\$ 33.1 \mathrm{~B})$ & China $(\$ 22.9 \mathrm{~B})$ & Cocoa Beans $(\$ 3.19 \mathrm{~B})$ & China $(\$ 13.7 \mathrm{~B})$ \\
\hline Iran & $\begin{array}{c}\text { Ethylene Polymers }(\$ 2.49 \mathrm{~B}) \\
\text { Iron Ore }(\$ 2.02 \mathrm{~B})\end{array}$ & $\begin{array}{c}\text { India }(\$ 9.1 \mathrm{~B}) \\
\text { Japan }(\$ 6.18 \mathrm{~B})\end{array}$ & $\begin{array}{l}\text { Rice }(\$ 2.46 \mathrm{~B}) \\
\text { Gold }(\$ 1.66 \mathrm{~B})\end{array}$ & $\begin{array}{r}\text { India }(\$ 5.4 \mathrm{~B}) \\
\text { Korea }(\$ 4.48 \mathrm{~B})\end{array}$ \\
\hline Israel & $\begin{array}{c}\text { Packaged Medicaments } \\
(\$ 5.94 \mathrm{~B}) \\
\text { Refined Petroleum }(\$ 4.13 \mathrm{~B}) \\
\text { Diamonds }(\$ 4.07 \mathrm{~B})\end{array}$ & $\begin{array}{c}\text { US }(\$ 12.4 \mathrm{~B}) \\
\text { China }(\$ 2.93 \mathrm{~B}) \\
\text { Palestine }(\$ 2.81 \mathrm{~B})\end{array}$ & $\begin{array}{c}\text { Crude Petroleum }(\$ 8.44 \mathrm{~B}) \\
\text { Diamonds }(\$ 4.21 \mathrm{~B}) \\
\text { Cars }(\$ 3.23 \mathrm{~B})\end{array}$ & $\begin{array}{c}\text { US }(\$ 6.96 \mathrm{~B}) \\
\text { China }(\$ 5.63 \mathrm{~B}) \\
\text { Germany }(\$ 4.58 \mathrm{~B})\end{array}$ \\
\hline Jordan & Potassic Fertilizers $(\$ 563 \mathrm{M})$ & US $(\$ 1.48 \mathrm{~B})$ & Refined Petroleum & Saudi Arabia $(\$ 4.1 \mathrm{~B})$ \\
\hline \multicolumn{2}{|c|}{ Published by Sciedu Press } & 13 & ISSN 1923-3981 & E-ISSN 1923-399X \\
\hline
\end{tabular}




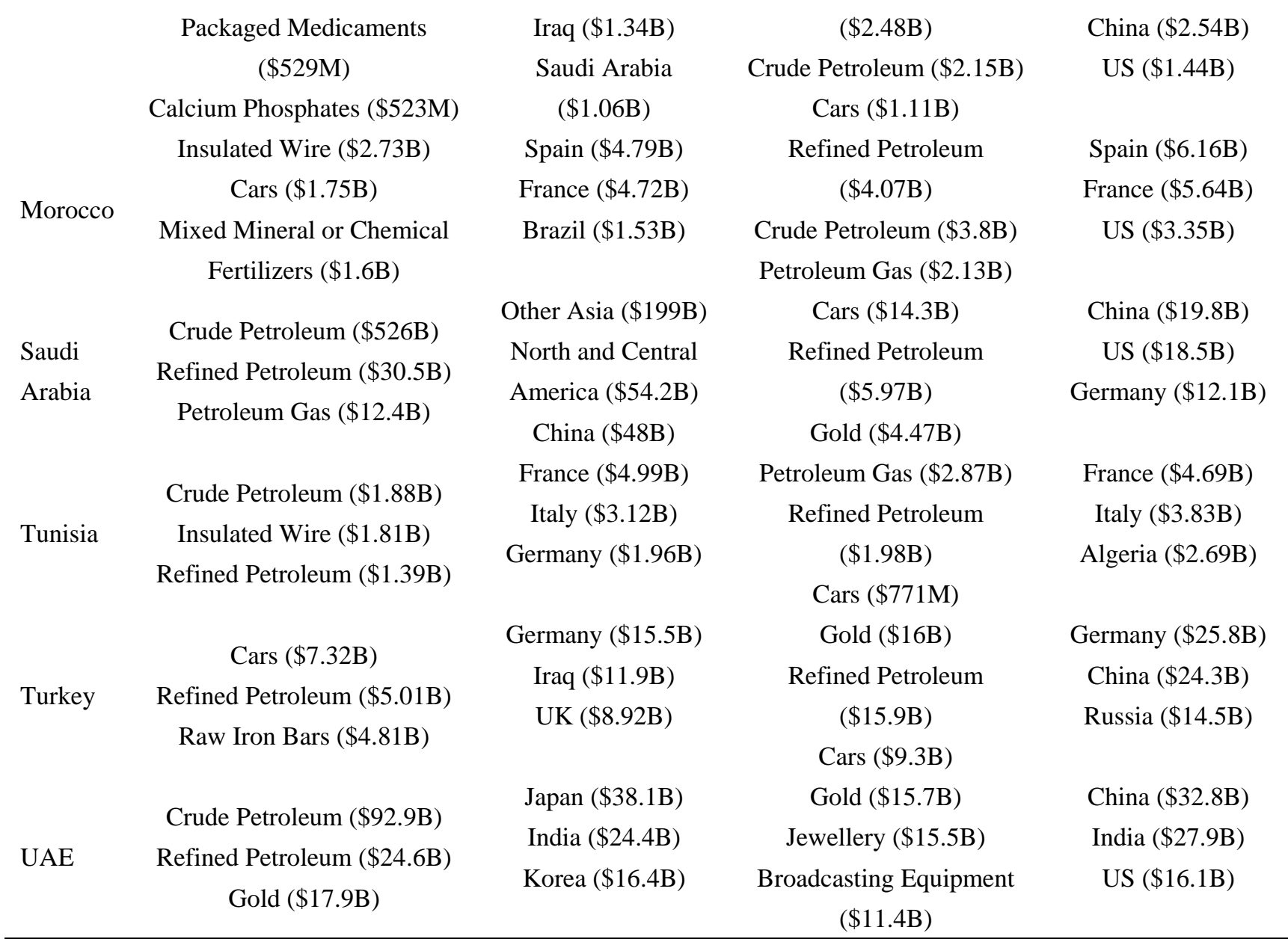

Source: The Observatory of Economic Complexity (MIT) (http://atlas.media.mit.edu/) 